\title{
L1 Interference in SLA: A Study on Turkish L2 Learners of English
}

\section{Sinan Çakır ${ }^{1}$}

\section{Type/Tür:}

Research/Araştırma

Received/Geliş Tarihi:

September 4/ 4 Eylül 2018

Accepted/Kabul Tarihi:

November 14/ 14 Kasim 2018

Page numbers/Sayfa No: 469-482

Corresponding

Author/İletişimden Sorumlu

Yazar: scakir@adiyaman.edu.tr

\section{$\checkmark$ iThenticate}

This paper was checked for plagiarism using iThenticate during the preview process and before publication. / Bu çalışma ön inceleme sürecinde ve yayımlanmadan önce iThenticate yazılımı ile taranmıştır.

Copyright $\odot 2018$ by

Cumhuriyet University, Faculty of Education. All rights reserved.
Abstract
This paper examines the role of L1 transfer in second language acquisition process. It aims to investigate if adult Turkish L2 learners of English make use of their L1 parameter values while dealing with the target subject-matter in L2 or not. It specifically focuses on four island constraints (Wh-island Constraint, Complex NP Island Constraint, Adjunct Island Constraint and Sentential Subject Constraint) in the target language. The data were collected online through a grammaticality judgment test and a wh-question formation test from an English control group ( $N$ : 58) and two learner groups (advanced, $N: 66$; intermediate, $N: 68$ ). The results of the study showed that the participants make use of the parameter values of the target language rather than leaning on the ones that their native language possesses. Their performance on the target subject-matter was rather similar to those of the control group members. The argument \& adjunct asymmetry that exists in their mother tongue was not observed in their L2 productions. These results show that their second language acquisition/learning process is constrained directly by UG rather than indirectly through L1. The implications of these findings to ELT classrooms might be that the differences between L1 and L2 should not be the main focus of the teaching learning activities. The main aim should be providing the necessary positive input for the language learners. In that case, they can reset the parameter values of the target language. Hence, the more they are exposed to the target language, the faster the acquisition process becomes.

Keywords: Second language acquisition, universal grammar, mother tongue influence, Turkish, English

\section{Suggested APA Citation/Önerilen APA Atıf Biçimi:}

Çakır, S. (2018). L1 interference in SLA: A study on Turkish L2 learners of English. Cumhuriyet International Journal of Education, 7(4), 469-482 http://dx.doi.org/10.30703/cije.457047

\footnotetext{
1 Assist. Prof. Dr., Adiyaman University, Faculty of Letters and Science, Department of English Language and Literature , Adiyaman/Turkey

Dr. Öğrt. Üys., Adıyaman Üniversitesi, Fen Edebiyat Fakültesi, İngiliz Dili ve Edebiyatı Bölümü,

Adıyaman/Türkiye

e-mail: scakir@adiyaman.edu.tr

ORCID ID: $\underline{\text { https:/ / orcid.org/0000-0002-7741-3706 }}$
} 


\title{
İkinci Dil Ediniminde Ana Dil Etkisi: İngilizceyi Öğrenen Türkler Üzerine Bir Çalışma
}

\begin{abstract}
Öz
Mevcut çalışma ikinci dil edinimi üzerindeki ana dil etkisini incelemektedir. Çalışmada, İngilizceyi ikinci dil olarak edinen Türklerin hedef konuda ana dillerinin parametrik değerlerini kullanıp kullanmadıkları araştırılmaktadır. Hedef dilde gözlemlenen dört ada yapısına odaklanılmıştır (Ne-Adası Kısıtlaması, Karmaşık Ad Öbeği Kısıtlaması, Eklenti Adası Kısıtlaması ve Tümcesel Özne Kısıtlaması). Çalışmanın verileri çevrimiçi olarak bir dilbilgisellik değerlendirme testi ve bir ne-sorusu oluşturma testiyle toplanmıştır. Ana dil konuşucularından oluşan bir kontrol grupla beraber ( $N$ : 58) İngilizce yeterlik düzeyine göre belirlenmiş iki öğrenici grubu oluşturulmuştur (İleri Düzey, $N$ : 66; Orta düzey, $N$ : 68). Çalışmanın sonuçları İngilizceyi ikinci dil olarak öğrenen Türklerin ana dillerinin parametrik değerlerinden ziyade hedef dilin parametrik değerlerini kullandıklarını göstermiştir. Hedef dilbilgisi yapıları üzerindeki performansları ana dil konuşucularına benzerlik göstermektedir. Ana dillerinde mevcut olan ana öğe \& eklenti bakışımsızlığı ikinci dil kullanımlarında gözlemlenmemiştir. $\mathrm{Bu}$ sonuçlar onların ikinci dil edinim/öğrenim süreçlerinin ana dil transferinden ziyade doğrudan Evrensel Dilbilgisi tarafından kısıtlandığını göstermektedir. Bu bulgular ışığında ülkemizdeki dil öğretim sınıfları için şu çıkarımları yapabiliriz: kaynak dil ve hedef dil arasındaki farklılıklar dil öğretim çalışmaların ana odak noktasını oluşturmamalıdır. Ana hedef öğrencilere yeterli doğal veriyi sunmak olmalıdır. Yeterince doğal veriye maruz kaldıkları takdirde, hedef dilin parametrik değerlerini başarıyla kullanabilmektedirler. Dolayısıyla, ne kadar çok doğal veriye maruz kalırlarsa, dil öğrenim süreçleri de o denli hızlanacaktır.
\end{abstract}

AnahtarKelimeler: İkinci dil edinimi, evrensel dilbilgisi, ana dil etkisi, Türkçe, İngilizce

\section{Introduction}

When Generative Grammar was introduced in the 1950s, the accessibility of Universal Grammar (UG hereafter) on first language started to be discussed among linguistic environments. However, in the following years, another debate started to take place among linguists: the availability of UG in second language acquisition (SLA hereafter). In this debate, the potential mother tongue interference has played one of the major roles. As Sauter (2002) states:

The role of the native language is one of the most extensively discussed theoretical issues of second language acquisition research. Even though there is consensus that the native language influences the non-native language in ways that extend beyond borrowing or falling back on the native language, there is little agreement about what and how much of the native language transfers into the non-native language (p. 1).

Hence, several studies have been conducted to determine how and to what extend mother tongue parameter values influence the SLA process. With regard to the role of L1 transfer in SLA, different hypotheses have been produced which can be gathered under three titles: (1) No Access, (2) Indirect Access and (3) Full Access accounts. According to the No Access Account, L2 acquisition process is not constrained by UG, neither directly nor indirectly through L1. In this approach, L2 acquirers are claimed to use different cognitive mechanisms in their acquisition process other than UG. Clahsen and Muysken (1986), Meisel (1997), and more recently, Han (2004) and Long (2007) are some of the followers of this account. The Indirect Access Account proposes that UG constrains L2 development only through L1. 
That is to say, only the features that are instantiated in L1 are available for L2 acquisition. Clahsen and Hong (1995), Schachter (1989; 1990), and more recently, Hawkins and Hattori (2006), Tsimpli and Dimitrakopoulou (2007) are some of the proponents of this account. The Direct Access Account proposes that UG is fully available in SLA. It claims that L2 acquirers transfer their L1 internal grammars and restructure them via UG operations upon being confronted with L2 data that cannot be accounted for by the L1 configurations. Schwartz and Sprouse (1996) and more recently Montrul, Foote, Perpinan, Thornhill and Vidal (2006), Tanner (2008), Rothman, Judy, Fuentes and Pires (2010) and Bond, Fiorentino and Banon (2011) are some of the scholars who adopted this view.

This paper ${ }^{2}$ aims to analyze the role of L1 transfer in SLA in the context of these three accounts. It aims to contribute to the ongoing debate on the role of UG and the mother tongue interference in L2 acquisition process. Naturally, while investigating the accessibility of UG in SLA, all aspects of the L2 acquisition process cannot be dealt with at once. A specific aspect of it should be investigated in order to be able to get valuable data. One of the grammatical structures that attract the attention of the scholars who carry out researches on the availability of UG in SLA is the island constraints on movements. The reason for this interest is that the acquisition process of such constraints is the poverty of stimulus issue. That is to say, they are not taught in formal education and they are not detected easily through observation. If such constraints are acquirable for L2 learners, it means that UG is accessible for them, if not, UG is inaccessible for L2 acquisition. The acquisition process of such locality constraints are still at the heart of such studies (e.g. Hawkins \& Hattori, 2006).

In respect to island constraints on wh-movement, Turkish and English behave similarly on some structures, yet they differ in some others. However, such similarities and differences originate from different sources. While the requirement for the overt wh-movement to Spec CP to satisfy the [uwh*] feature and the violation of island structures in this overt movement cause ungrammatical structures in English, the government and binding relationships between the $[\mathrm{Qu}]$-operator and wh-words in-situ cause (un)grammaticality in Turkish. (See the following parts to get more detailed information on the wh-movement phenomenon in English and Turkish). Such differences may play a role in the L2 acquisition of the island constraints. Nevertheless, as far as the Turkish \& English pair is concerned, the possible L1 transfer in the L2 acquisition of the island constraints on wh-movement has not been analyzed in the literature. The present study aims to fill this gap. Such a study may provide fruitful results to determine the role of UG and the possible mother tongue interference in SLA process. The study investigates the following research questions:

\footnotetext{
2 The present paper is a part of the $\mathrm{PhD}$ dissertation, which examines the validity of the 'Interpretability Hypothesis' proposed by Tsimpli, Dimitrakopoulou, Roussou and Kalaintzidou (2003), Hawkins and Hattori (2006), Tsimpli and Dimitrakopoulou (2007). This hypothesis claims that only the uninterpretable features which are instantiated in L1 are available for L2 acquisition process. There are several studies which support this hypothesis (Kong, 2005; Al-Thubaiti, 2007) or stand against it (Rothman, Iverson \& Judy, 2009; Mendez \& Slabakova, 2012). The findings of the dissertation stand against the Interpretability Hypothesis. The data obtained in the study showed that the uninterpretable [uwh] feature is available in L2 acquisition process, yet being exposed to natural input during the acquisition process has a vital role. The study suggests that positive input in the target language has an important role in determining the availability of UG in SLA.
} 
1. With regard to the target subject-matter, are the participants' L2 final state grammars constrained by UG?

2. If their final state grammars are constrained by UG, is this involvement direct or indirect through L1?

Before moving ahead, it is necessary to provide some basic information about the wh-construction and island phenomena in the source and target languages.

\section{Island Constraints and Wh-phrases in the Target Language (English)}

Island constraints are the structures that prohibit the movement of the elements to higher nodes in the derivation. The extraction of the items out of these structures causes ungrammaticality in the sentence. Such constraints were first introduced by Ross (1967) and extended since then. For instance, in the sentence below, the Complex NP Island Constraint is violated:

$(1)$ * When do you remember the young girl who you met?

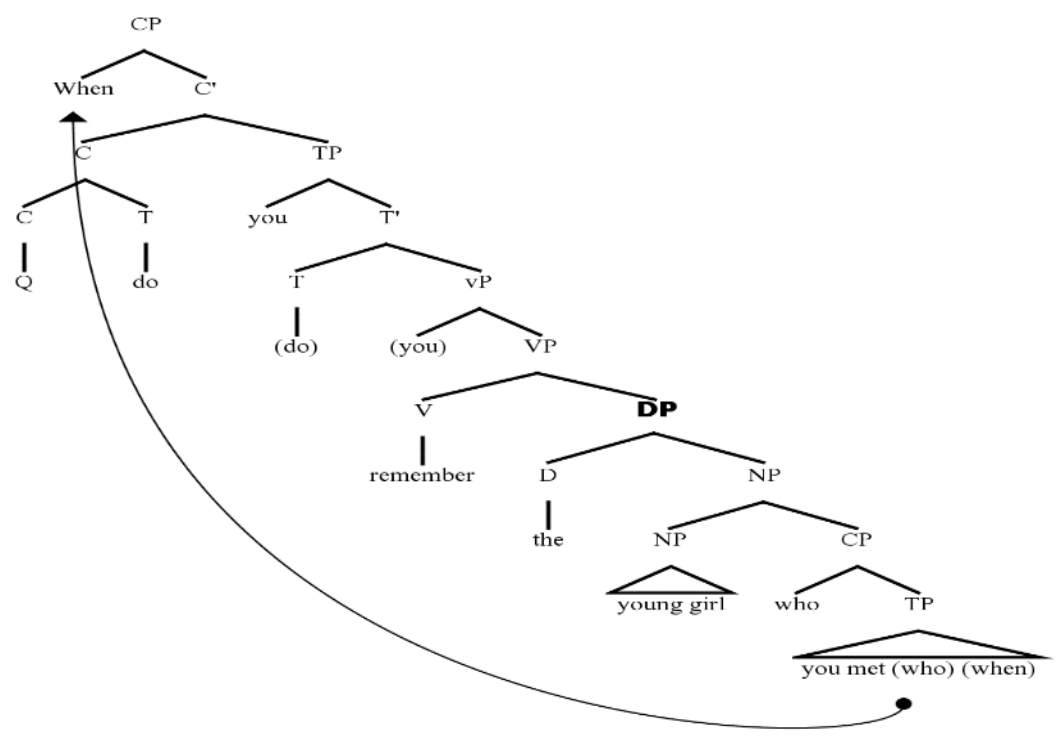

In this derivation, the embedded $\mathrm{CP}$ is c-commanded by a DP projection, which prohibits the upper movement of the elements. Hence, the movement of the wh-expression 'when' from the embedded CP to the matrix CP is not possible due to the existing DP. Such structures are traditionally called complex NP island constraint structures. In the following years, several other island constraints such as Wh-Island Constraint, Adjunct Island Constraint, Factive Island Constraint were proposed by the scholars such as Kiparsky and Kiparsky (1970), Chomsky (1973), Schafer (1995).

Island Constraints hold firmly in overt wh-movement languages such as English which have strong uninterpretable wh-feature [uwh*] in their matrix CPs. The extraction of both wh-arguments and wh-adjuncts out of island structures results in ungrammaticality in this language:

(2) a. *What did the thief run away [after he stole $\{$ what $\}$ ?

b. * Why did George go out [after he got angry with Sue $\{$ why $\}]$ ? 
In both (2a) and (2b), the wh-phrases originate within the embedded adjunct clauses and move to the matrix spec CP to check the [uwh*] feature that exists in this node. This movement, however, results in ungrammaticality due to the Adjunct Island Constraint which prohibits movement out of an adjunct structure.

As for other island structures such as Wh-Island Constraint and Sentential Subject Constraint, the extractions of both arguments and adjuncts out of such structures result in ungrammaticality as well (Adger, 2003). That is to say, island constraints hold both for arguments and adjuncts in this language.

\section{Island Constraints and Wh-phrases in the Source Language (Turkish)}

Wh-phrases remain in-situ both in main and subordinate clauses in Turkish (Akar, 1990; Kornfilt, 2003; 2008). The uninterpretable [uwh] feature is not strong in wh-insitu languages; therefore, wh-phrases do not move overtly to matrix CP. For such languages, it is asserted that the uninterpretable [uwh] is checked in an operatorbinding relationship (Aoun \& Li, 1993). According to this approach, the wharguments in-situ do not need a local antecedent in the minimal clause they occur. They can be directly bound by the wh-operators that originate in the matrix CPs. Therefore, they are not subject to island constraints. On the other hand, the operators of wh-adjuncts originate within the embedded $\mathrm{CP}$ and then move to the matrix spec CP node. This movement, however, is subject to island effects just like the movement of the wh-phrases in overt wh-movement languages. In other words, the adjunct whphrases are subject to island constraints since their operators move overtly out of island structures.

The adjunct \& argument asymmetry ${ }^{3}$ asserted by Aoun and Li (1993) seems to be valid for Turkish. That is to say, the interpretation of wh-adjuncts within island structures results in ungrammaticality in this language. On the other hand, argument wh-phrases can be interpreted within such structures without causing any ungrammaticality. The following sentences exemplify these cases respectively:
(3) a. Hirsiz [pro neyi
çaldiktan
sonra] koşarak
uzaklaştı?
Thief what ACC steal-FN-ABL after run-GER go away-PAST
'What did the thief run away [after he stole $\{$ what $\}$ '

\footnotetext{
${ }^{3}$ Aoun and Li (1993) exemplify the argument \& adjunct asymmetry observed in Chinese as follows (p. 203):

(4) a. Ni xihuan shei xie de shu?

You like who write DE book

'Who(x) such that you like the book $\mathrm{x}$ wrote?'

b. ${ }^{*} \mathrm{Ni}$ xihuan ta weishenme xie de shu?

You like he why write DE book

'Why $(\mathrm{x})$ you like the book he wrote $\mathrm{x}$ ?'

Both (4a) and (4b) are subject to classical Complex NP Constraint. While the interpretation of the argument whword is grammatical within this island structure, the interpretation of the wh-adjunct results in ungrammaticality. A similar asymmetry is observed in Turkish. Özsoy (1996) provides the following examples:
(5) a [[Kim-in yaz-dig-i] mektub]-u oku-du-n? Who-GEN write-FN-3SG letter-ACC read-PAST-2SG

*'Who did you read [the letter[\{who\} wrote]]?'

$\begin{array}{ccccc}\mathrm{b} *[\text { Adam-in } & \text { neden } & \text { yaz-dig-i] } & \text { mektup }] & \text { uzun? } \\ \text { Man-GEN } & \text { why } & \text { write-FN-3SG } & \text { letter } & \text { long }\end{array}$

*'Why is [the letter [the man wrote \{why\}]] long?'

Similar to Chinese, while (5a) is grammatical, (5b) is not.
} 
b. *Murat [pro Merve'ye neden kızdıktan sonra] dışarı çıkt?? Murat Merve-DAT why get angry-FN-ABL after out go-PAST 'Why did Murat go out [after he got angry with Merve \{why\}]'

Both of the sentences in (3) are subject to Adjunct Island Constraint. Nevertheless, while (3a) does not yield any ungrammaticality, (3b) is not grammatical. This argument \& adjunct asymmetry observed in Turkish is valid for other island structures such as Complex NP Island Constraint, Wh-Island Constraint and Sentential Subject Constraint as well (Özsoy, 1996).

Hence it is safe to conclude that wh-phrases in English and Turkish have different characteristics as far as the island constraints are concerned. Focusing on this difference, the purpose of this study is to assess the possible mother tongue influence on Turkish L2 learners of English. While dealing with the island structures in the target language, if they assess that wh-adjunct extractions are worse than that of wh-arguments, the reason for this situation may be the influence of their native language. On the other hand, if their performance on the target subject matter is not significantly different compared to that of the control group members, such a result may be viewed as an indication for the fact that their L2 acquisition process is constrained directly by UG.

\section{Method}

The study focuses on the acquisition of the four island constraints in the target language by Turkish L2 learners of this language. The target island constraints are: Complex NP Island Constraint, Sentential Subject Constraint, Adjunct Island Constraint and Wh-Island Constraint.

\section{Participants}

Two learner groups (advanced and intermediate) and a control group took part in the study. There were 58 participants in the control group (34 female, 24 male; mean age: 20,6). They are all native speakers of English living in Gainesville, the United States of America. They are the students at several departments of the University of Florida.

The participants in the learner groups are Turkish L2 learners of English. They are living either in Turkey or the USA. Their level of proficiency was determined through Michigan Placement Test, which contains 50 questions. In this test, the participants who scored better than 40 were placed in Learner Group 1 ( $N: 66 ; 38$ female, 28 male; mean age: 25,2$)$ and the ones who scored between 30 to 40 were placed in Learner Group 2 ( $N$ : 68; 44 female, 24 male; mean age: 24,5). The ones who scored lower than 30 were excluded from the study.

\section{Data Collection}

The data of the study were collected through a grammaticality judgment test (GJT hereafter) and a wh-question formation task (WQFT hereafter). These tests are frequently used in the studies that focus on UG-SLA relationship. As White (2003) states, they can be used to find out whether sentences which are ruled out by principles of UG are also disallowed in the interlanguage grammar (p.18). In the present study, they were given to the participants online through a survey program. 
Before starting the tests, the participants were required to provide certain information, such as their age, gender, education etc.

The grammaticality judgment test. The GJT contained 40 items. 20 of these test items did not contain any island violations. In the other 20 items, one of the target island structures was violated. Half of these test items contained argument extractions out of the target island structures, and the other half involved those of wh-adjuncts. The participants were asked to assess the test items in a $-2,+2$ scale $(-2$ : totally grammaticality unacceptable, -1 : grammatically unacceptable, 0 : not sure, 1 grammatically acceptable, 2: totally grammatically acceptable). (Please see the appendix for sample test items).

The wh-question formation task. The WQFT contained 25 items. In 20 of them, the contexts given to the participants manipulate the participants into violating one of the target island constraints. In such test items, short dialogues were given to the participants. After reading these dialogues, they were required to set up whquestions the replies of which had already been given underneath. That is to say, the participants were required to set up a wh-question which could be a suitable question for the given reply. In the test, they were allowed to use only the given whphrases (Please see the appendix for sample test items).

\section{Findings \& Discussion}

The data obtained in the study are shown in two figures. The results for the GJT and the WQFT are presented separately.

\section{Results for the Grammaticality Judgment Task}

The GJT results are displayed in Figure 1 below. In this figure, when the numbers are closer to $(+1)$, it means that the participants assessed the test items as grammatically acceptable. On the other hand, when the numbers get closer to the (-1), it means that they judged the test items as grammatically unacceptable. For the ease of the readers, the findings were transformed to $(+1,-1)$ scale although the test was carried out in $(+2,-2)$ scale originally.

Figure 1. The results for the GJT

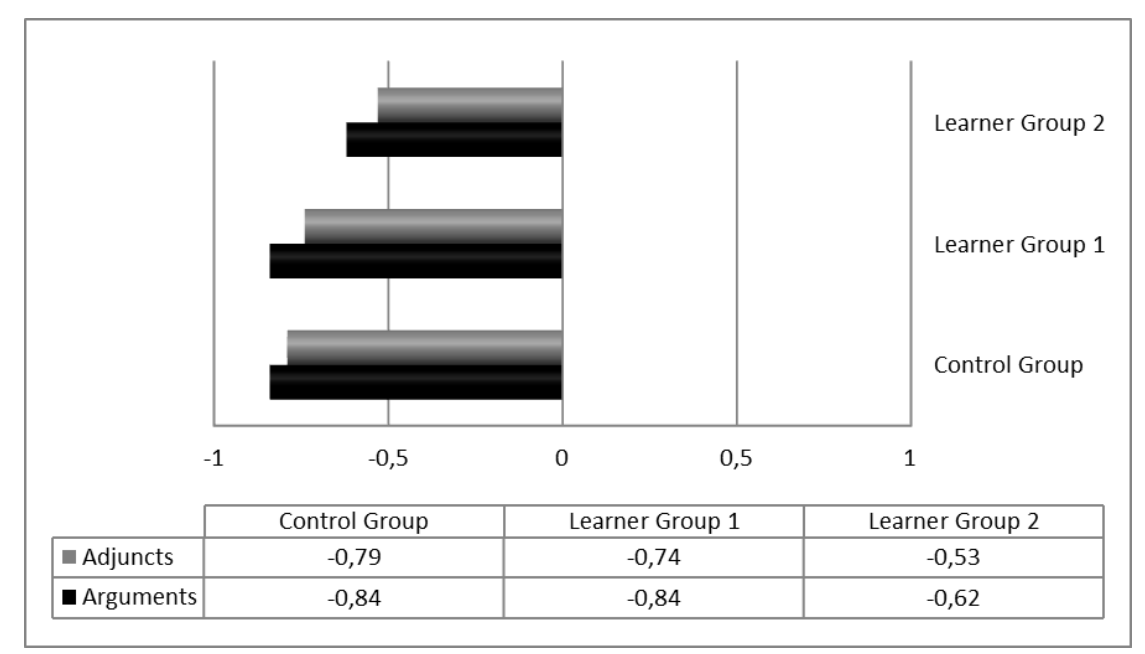


According to the Independent Samples T-Test results, there is no significant difference between the Control Group and the Learner Group $1(0.298<0.05)$. Almost in equal numbers, the members of both groups detected ungrammatical sentences in which one of the four target island constraints are violated. This means that the uninterpretable [uwh*] feature must have been acquired by the highly proficient L2 learners of English as they could perform as well as the native speakers of this language in the target subject-matter, which indicates the availability of UG in their L2 acquisition process. On the other hand, the performance of the Learner Group 2 was significantly worse than the other groups $(0.001<0.05)$. Since they are not fully proficient in English, this result can be regarded as a performance related problem rather than unavailability of the target uninterpretable feature. When they are exposed to more input and become more proficient in the target language, they are likely to perform as well as native speakers of English.

What is striking in the figure is the similarity in the performances of all groups with regard to adjunct \& argument distinction. The participants in all groups assessed that the extractions of arguments out of island structures are worse than extractions of adjuncts. Though adjunct extractions are considered to be worse than that of arguments universally, the data of the present study demonstrated opposing results. The reason for this discrepancy might be that some participants of the study might have taken the reading in which the wh-adjuncts adjoined to the matrix clauses rather than the embedded clauses. Although this option was blocked in the given test items by providing another adjunct in the main clause, they might have forced this reading in order to avoid making island violations. On the other hand, the arguments can only merge to the embedded clauses in the given test items and it is not possible to follow such a strategy to escape island violations. This means that some participants were aware of the fact that islands are violated in both argument and adjunct extractions, but they treated adjuncts more flexibly by forcing their matrix clause reading. This might be the reason behind the case that argument extractions were assessed to be worse than adjunct extractions rather than being equal.

As for the mother tongue influence in L2 learners of English, the adjunct \& argument asymmetry that exists in Turkish was not observed in the performances of the learner groups. Their performance was in parallel with that of the control group members. That is, all groups assessed that argument extractions were worse than adjunct extractions in a similar manner. If the learner group members were making use of the parameter values of their native language, they should have assessed the adjunct extractions to be remarkably worse than that of the arguments. Since the data of the study contain opposing results, it is not possible to consider L1 transfer in such structures. Even the low proficiency group members performed in parallel with the native speakers of English while dealing with arguments and adjuncts. This means that the parameter values of the mother tongue is not influential even for the participants who are not fully proficient in English. Though they produced poorer results compared to other groups in general, they did not treat arguments and adjunct differently, which means that their acquisition process is constrained by UG directly rather than indirectly through L1. 


\section{Results for the Wh-Question Formation Task}

The results for the WQFT are demonstrated in Figure 2 below. In this figure, the percentages of the ungrammatical sentences, which contain the violation of one of the four target island constraints, are displayed.

Figure 2. The results for the WQFT

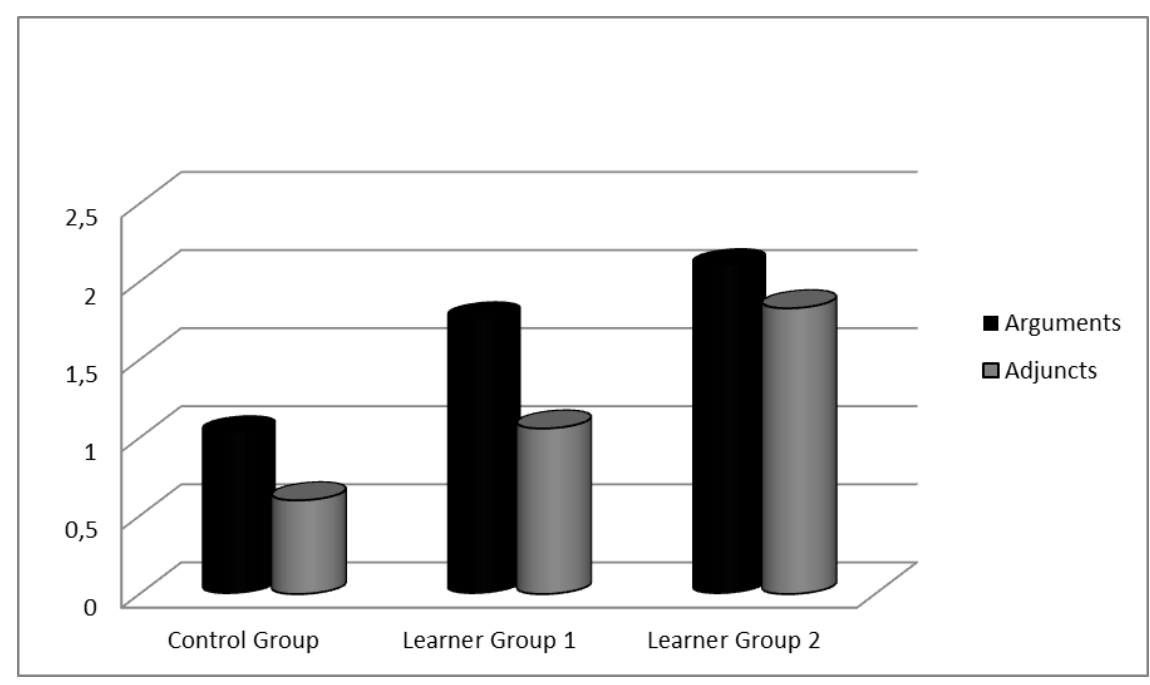

In the WQFT, the participants were required to set up wh- questions by making use of the given context which forced them to make island violations. However, it was also possible for them to follow any other strategy to escape violating islands. As a matter of fact, very small number of the productions of the participants contained island violations. In the great majority of the responses, they could successfully escape violating the target island structures. As demonstrated in Figure 2, the highest number of island violations was produced by the participants in the low proficiency group which is lower than 4 percent (when the arguments and adjuncts are counted together). This means that more than 96 per cent of their productions did not contain island violations. This situation is a further proof for the fact that the [uwh*] feature is available even in the lower levels of the L2 acquisition process. As for the higher proficiency group, only less than 3\% of their productions contained island violations and there was not any significant difference in the performances of all groups $(0.512<0.05)$.

As for the possible mother tongue influence, the argument \& adjunct asymmetry that exists in Turkish is not observable in the performances of L2 learners in this task, either. In fact, the results of this task are rather similar to that of the first task. Both learner groups performed in parallel with the control group members. They did not produce more ill-formed sentences while they were dealing with adjuncts. If they were making L1 transfer, they would have made more island violations while setting up sentences that contained adjuncts. Since the findings of the study stand against this possibility, it is safe to conclude that their acquisition process is constrained directly by UG rather than indirectly through L1.

These findings imply that the formal teaching activities in L2 classrooms should not take L1 transfer as a base. In other words, the teaching- learning activities in such classrooms should not primarily focus on the distinctions between the source 
and the target languages. When the L2 learner of a language is subject to enough positive input in the target language, $\mathrm{s} /$ he can reset the necessary parameter values in the target language. Hence, the main aim of the teaching-learning activities in formal settings should be providing necessary positive input for the L2 learners.

\section{Conclusion}

The aim of the study was to examine the possible role of L1 transfer in L2 acquisition process. The target (English) and source (Turkish) languages differ with respect to handling arguments and adjuncts within island structures. English obeys the island constraints on wh-movement but these constraints hold only for wh-adjuncts in Turkish. While it is possible to interpret wh-arguments out of the islands in Turkish, it is not possible to do the same for wh-adjuncts.

The adjunct \& argument asymmetry observed in Turkish is a suitable research field for the studies that focus on UG-SLA relationship. It is a poverty of stimulus issue which may provide valuable data to detect the (direct or indirect) availability of UG in L2 acquisition process. Though such asymmetries are frequently examined in the world literature, there have not been any studies that focus on the argument and adjunct asymmetry observed in the extraction of the wh-phrases out of the island structures in Turkish.

Hence, if Turkish L2 learners of English were under the influence of their mother tongue while dealing with the island structures in the target language, they would treat arguments and adjuncts differently. That is, they would assess that adjunct extractions are remarkably worse than argument extractions. On the other hand, if their second language acquisition process were constrained by UG directly, they would not make such a distinction and they would perform in parallel with native speakers of English.

The results of the study showed that Turkish L2 learners of English make use of the parameter values of the target language rather than leaning on the ones that their native language possesses. Their performance on the target subject-matter is rather similar to that of the control group members. The argument and adjunct asymmetry that exists in their mother tongue is not observed in their L2 productions. These results show that UG directly constrains their L2 acquisition process. These findings are consistent with the previous studies that were carried out by Montrul et al. (2006), Tanner (2008), Rothman et al. (2009), Rothman et al. (2010), Bond et al. (2011) and Mendez and Slabakova (2012) and stand against the findings obtained by Tsimpli et al. (2003), Kong (2005), Hawkins and Hattori (2006), Tsimpli and Dimitrakopoulou (2007), Tsimpli and Mastropavlou (2007) and Al-Thubaiti (2007). As far as the target subject-matter is concerned, UG appears to be fully available for Turkish L2 learners of English. These learners do not lean on the parameter values of their mother tongue while dealing with the target structures.

Nevertheless, the assertions of the study are limited to the data obtained from the participants of the study. Yet, the sample group that has been analyzed sets an example for the overall L2 acquisition process with regard to the acquisition of the target subject-matter by Turkish L2 learners of English. Further studies could test the assertions of the study on a larger scale, focusing on the other island constraints such as the Coordinate Structure Constraint, the Negative Island Constraint and the Factive Island Constraint which are not dealt with in the present study. 
The implications of these findings for English Language Teaching classrooms in Turkey might be that the teaching-learning activities should not lean on L1 transfer. That is to say, the differences between L1 and L2 should not be the main focus of the teaching-learning activities. As the present study suggests, when language learners are subject to enough positive input in the target language, they are capable of resetting the necessary parameter values in accordance with the ones that the target language has. Therefore, teaching activities should mainly focus on providing the necessary positive input for the learners. The more they are exposed to the target language, the faster the acquisition process becomes.

\section{References}

Adger, D. (2003). Core syntax: A minimalist approach, Oxford: Oxford University Press. Akar, D. (1990). Wh-questions in Turkish. (Unpublished M.A. thesis). Boğaziçi University, İstanbul.

Al-Thubaiti, K. (2007). Age effects on the acquisition of uninterpretable features by proficient Saudi Arabic speakers of English. In N. Hilton, R. Arscott, K. Barden, A. Krishna, S. Shah \& M. Zellers (Eds.), The Proceedings of the 5th University of Cambridge Postgraduate Conferences in Language Research (pp. 1-8). Cambridge: Cambridge University Press.

Aoun, J., \& Li, Y.A. (1993). Wh-elements in-situ: syntax or LF? Linguistic Inquiry, 24(2), 199-238.

Bond, K., Gabriele, A., Fiorentino, R., \& Banon, J. A. (2011). Individual differences and the role of the L1 in L2 processing: An ERP investigation. In J.

Herschensohn \& D. Tanner (Eds.), The Proceedings of the 11th Generative Approaches to Second Language Acquisition Conference, (pp. 17-29). Somerville, MA: Cascadilla Press.

Clahsen, H., \& Muysken, P. (1986). The availability of universal grammar to adult and child learners: A study of the acquisition of German word order. Second Language Research, 2, 93-119. https:/ / doi: 10.1177/026765838600200201

Clahsen, H., \& Hong, U. (1995). Agreement \& null subjects in German L2 development: New evidence from reaction-time experiments. Second Language Research, 11, 57-87. https:/ / doi: 10.1177/026765839501100103

Chomsky, N. (1973). Conditions on transformations. In S. Anderson \& P. Kiparsky (Eds.), A festschrift for Morris Halle (pp. 232-86). New York: Holt, Reinhart \& Winston.

Han, Z. H. (2004). Fossilization in adult second language acquisition. Clevedon: Multilingual.

Hawkins, R., \& Hattori, H. (2006). Interpretation of English multiple wh-questions by Japanese speakers: A missing uninterpretable feature account. Second Language Research, 22(3), 269-301. https:/ / doi: 10.1191/0267658306sr269oa

Kiparsky, P., \& Kiparsky, C. (1970). Fact. In M. Bierwisch \& K. Heidolph (Eds.), Progress in Linguistics (pp. 69-76). The Hague: Mouton.

Kong, S. (2005). The partial access of universal grammar in second language acquisiton: an investigation of the acquistion of English subjects by L1 Chinese speakers. East Asian Linguistics, 14, 227-265. https:// doi: 10.1007/s10831-0051602-6 
Kornfilt, J. (2003). Unmasking the Sentential Subject Constraint in Turkish. In A. S. Özsoy, D. Akar, M. Nakipoğlu Demiralp, E.E. Erguvanlı Taylan \& A. Aksu Koç (Eds.), Studies in Turkish linguistics (pp. 95-105). İstanbul: Boğaziçi University Press.

Kornfilt, J. (2008). Some observations on Turkish/Turkic RCs. Presented as a paper in Leipzig Spring School on Linguistic Diversity; MPI-EVA Conference, Leipzig, Germany.

Long, M. (2007). Problems in SLA. Mahwah, New Jersey: Lawrence Erlbaum Associates.

Meisel, J. (1997). The acquisition of the syntax of negation in French and German: Contrasting first and second language development. Second Language Research, 13, 227-263. https:/ / doi: 10.1191/026765897666180760

Mendez, T. L., \& Slabakova, R. (2012). The Interpretability Hypothesis again: A Partial replication of Tsimpli \& Dimitrakopoulou (2007)". International Journal of Bilingualism, 1(1), 1-21. https:/ / doi: 10.1177/1367006912448125

Montrul, S., Foote, R., Perpinan, S., Thornhill, D., \& Vidal, S. (2006). Full access and age effects in adult bilingualism: An investigation of Spanish accusative clitics and word order. In N. Sagarra \& A. J. Toribio (Eds.), In the proceedings of the 9th Hispanic Linguistics Symposium (pp. 217-228). Somerville, MA: Cascadilla Press.

Özsoy, S. (1996). A' dependencies in Turkish. Presented as a paper in VI. Turkish Linguistics Conference. The School of Oriental and African Studies, London, The United Kingdom.

Ross, J. R. (1967). Constraints on variables in syntax. (Unpublished doctoral dissertation). Massachusetts Institute of Technology, Cambridge, MA.

Rothman, J., Iverson, M., \& Judy, T. (2009). Bound variable, split antecedent and ellipsis interpretations in L2 Portuguese: implications for L2 acquisition theories. Estudos da Lingua, 7(2), 261-300.

Rothman, J., Judy, T., Fuentes, P. G., \& Pires, A. (2010). On The (Un)-ambiguity of adjectival interpretations in L2 Spanish: Informing debates on the mental representations of L2 Syntax. Studies in Second Language Acquisition, 32, 47-77. https:/ / doi: 10.1017/S0272263109990258

Sauter, K. (2002). Transfer and Access to universal grammar in adult second language acquisition. (Unpublished PhD Dissertation). University of Groningen, Groningen.

Schachter, J. (1989). Testing a proposed universal. In S. Gass \& J. Schachter (Eds.), Linguistic perspective on second language acquisition. Cambridge: Cambridge University Press.

Schachter, J. (1990). On the issue of completeness in second language acquisition. Second Language Research, 6, 93 - 124. https:/ / doi: 10.1177/026765839000600201

Schafer, R. (1995). Negation and verb second in Breton. Natural language and linguistic theory, 13, 135-172.

Schwartz, B. D., \& Sprouse, R. A. (1996). L2 cognitive states and the Full Transfer/Full Access model. Second Language Research, 12, 40-72. https:/ / doi: $10.1177 / 026765839601200103$ 
Tanner, D. (2008). Agreeing that agreement isn't the problem. In M. Bowles (Ed.), In the proceedings of the 2007 Second Language Research Forum, (pp. 22-34). Somerville, MA: Cascadilla Press.

Tsimpli, I. M., Dimitrakopoulou, M., Roussou, A., \& Kalaintzidou, M. (2003). Clitics and determiners in the Greek L2 Grammar. In J. M. Liceras, H. Zobl \& H. Goodluck (Eds.), The proceedings of the 6th Generative Approaches to Second Language Acquisition Conference, (pp. 331-339), Somerville, MA: Cascadilla Press.

Tsimpli, I. M., \& Dimitrakopoulou, M. (2007). The Interpretability Hypothesis: evidence from wh-interrogatives in second language acquisition. Second Language Research, 23(2), 215-242. https:/ / doi: 10.1177/0267658307076546

White, L. (2003). Second Language acquisition and universal grammar. Cambridge: Cambridge University Press.

\section{Appendix 1: Sample test items}

\section{Grammaticality Judgment Test}

Judge the grammatical acceptability of the sentences given below by using the following scale:
a) -2 points: Totally Grammatically Unacceptable
b) -1 point: Grammatically Unacceptable
c) Not sure
d) 1 point: Grammatically Acceptable
e) 2 points: Totally Grammatically Acceptable

1. Who did Jack tell you when he had seen?

2. What does Mary love the boy who plays in the orchestra?

3. Why was the baby crying because her mother had gone out?

4. When do you think who bought these books?

\section{Wh-Question Formation Test}

Fill in the blanks to form a grammatical wh-question. The sentence given below the blanks should be a possible answer for the wh-question you formed. (Note: There is $\mathrm{NO}$ exact response, and whatever you produce is acceptable. Yet, please try to ask complex questions that cover the responses FULLY. Please do not to produce simple questions such as 'Where is John?' that address only half of the response).

Thomas: What is Jim doing right now?

Sue: He is reading a book. He bought it yesterday.

1 - When .................................?

Jim is reading the book which he bought yesterday.

William: Matthew seems very angry. Do you know why?

Beth: He got angry after learning the results of the exam.

2- What ..?

Matthew got angry after learning the results of the exam. 


\section{Authors' Biodata / Yazar Bilgileri}

Sinan Çakır graduated from the Department of Foreign Language Education, Middle East Technical University, Ankara, in 2002. He received his MA and PhD degrees in the Department of English Linguistics, Hacettepe University, Ankara, in 2006 and 2014 respectively. Currently he is working as an assistant professor in Adiyaman University, Department of English Language and Literature. His research interests include cognitive linguistics, generative grammar, and second language acquisition.

Sinan ÇAKIR Orta Doğu Teknik Üniversitesi, Yabancı Diller Eğitimi Bölümünden 2002 yılında mezun oldu. Hacettepe Üniversitesi, İngiliz Dilbilimi Bölümünden 2006 yılında yüksek lisans derecesini, 2014 yılında da doktora derecesini aldı. Halen Adıyaman Üniversitesi, İngiliz Dili ve Edebiyatı Bölümünde doktor öğretim üyesi olarak çalışmaktadır. Araştırma alanları arasında bilişsel dilbilim, üretimsel dilbilgisi ve ikinci dil eğitimi yer almaktadır. 